UDK: 336.71658

POSLOVNA EKONOMIJA BUSINESS ECONOMICS

Godina XI

Pregledni rad

Broj 2

Str $29-42$

doi: 10.5937/poseko12-15672

PhD Niccolò Paoloni, ${ }^{1}$

Roma Tre University, Rome, Italy,

Business Studies Department.

\title{
THE RELATIONSHIP BETWEEN BANKS AND COMPANIES: THE LITERATURE REVIEW
}

\begin{abstract}
This paper aims at reviewing the national and international literature on the lending relationship between banks and companies in Italy in light of the regulatory changes introduced by the Basel Committee in its various versions, in order to understand the "state of the art" and if and to what extent these issues have been dealt with in the various studies so far.

This article is based on a revision of the literature on the changed bank-company relationship in the post-economic crisis years. To this purpose, a bibliographic research was conducted on Scopus, using a series of selected keywords. The publications identified were analyzed and classified, in an attempt to determine the main topics and the results obtained thanks to the research and analysis carried out to-date.

This work contributes to the literature on the subject of the bank-company relationship and proposes a new perspective applied to an issue of great relevance in a period of economic recovery when financial support to companies is of crucial importance. Our revision of the literature highlights that this issue is not deeply studied as far as search for and availability of external sources of financing are concerned, which gives us the possibility to identify new questions and find new solutions to the problems connected with the sustainability of both public and private investments.
\end{abstract}

${ }^{1}$ niccolo.paoloni@uniroma3.it 
Key words: Banks, Companies, Credit, Italian Banks, Economic crisis, Regulation

\section{INTRODUCTION}

Due to their nature and characteristics, banks and companies have crossing destinies. The period of crisis and turbulence which has been striking the economic and financial system as from 2007 and the far-reaching effects of recession and stagnation of the economic system lead us to meditate on the supply and demand of financial resources, keeping in mind that this link is indissoluble.

The presence of a financial system allows those who operate within the same to have a functional infrastructure to make crucial economic choices for productive investments and asset management.

We may then affirm that the financial system is complementary to and indispensable for the productive system to organize economic activities.

The above highlights the existence of a mutual dependence relationship between real economy and financial economy: each financial system draws its own peculiarities from the choices and conducts of the reference system's economic operators and, vice versa, real economy is influenced by the financial system itself as regards its perspectives, capabilities and determination of investments.

During this period of crisis, the financial system underwent an evolution, and an ensuing restructuring, that led to a progressive change in the relationship between banks and companies.

The turbulence which affected large financial and corporate entities has contributed to accelerate the restructuring process, in particular in respect of the supervisory system, in order to assure the utmost stability of the financial system.

Following a series of regulatory changes introduced by the Basel Committee $^{2}$, the Italian banking system is experiencing a transition from a local or domestic dimension to being integrated in the European system, with Community rules and supervisory systems that should make the Italian system more and more similar to those of the main European Countries.

\footnotetext{
2 The Basel Committee on banking supervision is an international organization created by the Governors of the central banks of the ten most industrialized countries (G10) at the end of 1974. The Basel Committee operates under the patronage of the Bank for International Settlements.
} 
In this respect, the main question relates to the capability of such system to bring improvements, benefits and new opportunities for the reorganization and recovery of the national entrepreneurial system.

RQ1: What issues are most dealt with in literature which concern the bank-company relationship?

RQ2: Did the rules governing bank-company relationships influence the economic system and the business fabric?

This paper will answer the above research questions based on the following approach.

The second paragraph will further explain the method used, the research protocol and the data set. Paragraph three will analyse the existing literature on the subject at issue and the in last part the results obtained will be discussed.

\section{METHOD AND LETERATURE REVIEW}

In order to illustrate a revision of the literature on the credit relationship between banks and companies in Italy, we decided to look for academic contributions on Scopus database.

As a matter of fact, Scopus is a bibliographic database containing abstracts and citations of articles published in academic magazines where it is possible to run a search by keywords and appropriate parameters thus finding many scientific research publications.

Our research protocol concerns:

Determination of the search field, within which the different bibliographic sources will be analyzed. We therefore decided to limit our search to those document having an economic and financial relevance.

Determination of the reference timeframe for the detection of the documents. We decided to search for publication as from 2014, because the effects of the economic crisis started to be felt as from those year, and also because national and Community rules on banking became effective in that same year. Our search covers this period until the month of May 2017.

Selection of keywords to find the document through the Scopus search engine. To this purpose we combined the words "bank credit" \& "company" and subsequently "bank credit", "company" \& "Italy", and lastly "Italian bank";

Perspective/model/reference framework for the analysis of the documents detected. The method used to analyze the results obtained is connected to the search queries we selected; then the content of the documents 
was evaluated with reference to the impact of the new banking legislation on the bank-company relationship in Italy.

Our bibliographic research was accomplished through a double level of analysis corresponding to the two main research questions. On one hand we analyzed the publications dealing with the changes introduced by the new national and Community rules on banking. On the other hand, we focused on the impact this changed legislation had on the international economic and financial system.

\section{The data set}

The method followed to collect data is explained below with reference to the number of articles, the kind of magazines and the nationality of the authors.

As already mentioned, the search was made through the search engine "Scopus". This tool was chosen because it is a database of abstracts and citations of research literature, it is very used in Italy and really simple to search documents, more than half of the contents of Scopus come from European, publications. Currently, the database contains about 40 million records, half of which are related to a recent publication (78\% of which are complete with bibliography). $80 \%$ of the total records are complete with abstracts.

This database was created by the publishing house Elsevier ${ }^{3}$ in 2004 .

Scopus is updated regularly and offers around 25,000 articles from over 5,000 international publishers including: 16,500 magazines subjected to peer reviewing in the scientific, medical and social fields; 600 trade publications; 350 book publishers; a coverage including global conferences with 3.5 million conference papers mainly in English.

This portal gives direct access to the abstracts and full articles searched while, with and institute or private subscription it is only possible to obtain basic information relating to each author without a registration to the portal.

We tried to put some keywords in the search engine in order to detect all the works and authors dealing with the subject of the relationship between banks and companies.

By simply inserting the words "bank-company" or "bank-company relationship" we obtained a large number of articles, books, reviews and papers treating, also marginally, this issue.

\footnotetext{
${ }^{3}$ A Reed-Elsevier Group company, it is the world's largest medical and scientific publisher. With headquarters in Amsterdam, the company operates in 24 countries with more than 7,000 employees.
} 
We therefore needed to narrow the field of the search and determine more specific keywords for this subject, by inserting in the search engine Scopus the words: "Bank credit - company" and limiting our query only to data starting from 2014, we obtained 229 results with very diverse contents which we classified in an excel file containing various fields and subdivision criteria.

For each result obtained we considered: Title, name and origin of the author, kind of work (article, book, paper, conference or other event proceeding, review of existing articles, etc..), volume of publication, keywords indicated by the author and abstract.

A classification of this kind made it simpler to view the different documents based on the decree of interest and usefulness to the purpose of preparing this analysis.

This first analysis of the literature highlighted that among the 229 works obtained, less than ten were really useful for and inherent to our research questions and, specifically, all or almost all were written by Italian authors.

In a good number of cases, the documents found deal with issues connected with emerging countries and the role plaid therein by the banking system (Gou Q., et al. 2016, Pg 1-23"), the benefits the bank-company relationship may give to these countries and more specific subjects such as risk analysis in this kind of realities (Shafi A.A., et. al. 2016, Pg 1679-1686) or the use of special advanced technologies (Obokoh L.O., et. al. 2016. Pg 71-81).

Other studies discuss banking regulation and the role of rules on the level and composition of capital as well as the impact on the territory and the real economy at Community level (Bartolini M., et. al. 2014 Pg 43-67) or in specific countries such as China, Japan, Tunisia, South Africa and other African countries (Saeed A., et. al. 2015 Pg 503-524).

Based on the above analysis, we decided to narrow the field of the search in order to find more easily and directly those subjects that were most interesting in respect of our research questions.

Therefore, we decided to add the word "Italy" to the previously used "Bank credit - company" thus searching "Bank credit - company, Italy" only selecting documents written as from 2014.

With this kind of search we obtained 6 results that we will analyze hereinafter.

Only one document is of relevance for the kind of research we are conducting, as it deals with the effects the capital requirements the Community regulation requires from banks and credit policies have on the economic and financial system. This document is entitled: Leo S., Capital requirements and credit policies in Italy: what effects do they have? (Leo S., 2016 Pg 84-105).

Other three papers deal with subjects that relate to the issue of this research work, however without focusing on its specific topic. These are: 
Riccio G., Direct access to the debt capital market by unlisted companies in Italy and the effects of changes in civil Law: An empirical investigation. (Riccio G., 2016 Pg 179-193), La Rocca M., Deloof M., Local financial development and the trade credit policy of Italian SMEs (La Rocca M., et. al. 2015 Pg 905-924), "Peruta M.R.S., Campanella F., Giudice M.D., Knowledge sharing and exchange of information within bank and firm networks: The role of the intangibles on the access to credit (Peruta M.R.S, et. al. 2014 Pg 10361051).

Conversely, the two remaining papers are not directly related to the subject at issue and therefore are not useful to the drafting of our paper. (Stefani M.L. et. al. 2015, Pg 165-201), (Modina M., et. al. 2014, Pg 1537-1554).

As we have detected few sources in literature at national level on the issue of the bank-company relationship in light of the post-economic crisis changed regulation, we decided to continue our enquiry adding new keywords in the search engine Scopus, that is "Italian Bank".

The inclusion of these keywords allowed us to obtain 211 results, most of which were papers on general issues concerning the Italian banking system, the bank credit market in general, corporate governance of credit institutions and the management of non-performing loans.

Also in this case, only few articles were interesting and relevant for our research.

The documents to be taken into consideration, in addition to those mentioned above and also found with the second search changing the keywords, are the following: (Brighi P., et. al. 2016, Pg 1-10), (Rossi S.P.S et. al. 2015, Pg 1-193), (Gallo M. et. al. 2015. Pg 67-84), (Bartolini M., et. al. 2014 Pg 43-67), (Borri N., et. al. 2014 Pg 21-38), (Bartoli F., et. al. 2014 Pg 245-264), (Albertazzi U., et. al. 2014. Pages 387-40).

In light of the results obtained, we can state that it is difficult to find specific international literature on the changed relationship between banks and companies, in Italy, after the economic crisis and the introduction of the various national and European regulations.

This search at international level which resulted in few useful sources found and the lack of any literature on this topic leads us to think that a further examination of this issues could contribute to a better understanding of the dynamics of the relationship between companies and credit institutions in Italy both from an academic and professional points of view.

\section{DISCUSSION}

Following the above analysis of the literature relating to the first research question, we can state that the first search made using the words "bank credit, 
company" showed that the subjects most dealt with and more numerous concern the description and development of the bank-company relationship in emerging countries and in particular in African and Asian countries.

As evidenced above, more than $50 \%$ of the articles found with this kind of search concern issues concerning the emerging countries from various points of view such as the conditions to access credit, the many kinds of credit relationships that may be found between credit institutions and entrepreneurial systems in these countries, credit regulation and credit risk.

As to the other articles, $15 \%$ deal with topics referred to the United States of America, $20 \%$ to European countries and only $10 \%$ to Italy.

In light of these results, which are of little interest as far as Italy is concerned, we made a new search adding the word "Italy" alongside with "bank credit, company", thus finding six documents, four of which previously mentioned - of special interest to the purpose of the research question.

Table 1 - The data set of selected documents

\begin{tabular}{|c|c|c|c|}
\hline Key Words & $\begin{array}{c}\text { Number of } \\
\text { documents } \\
\text { extracted }\end{array}$ & $\begin{array}{c}\text { Nationality of } \\
\text { authors }\end{array}$ & Journal/Conference Proceeding \\
\hline $\begin{array}{c}\text { Banks Credit, } \\
\text { enterprise }\end{array}$ & 229 & $\begin{array}{l}\text { The majority of } \\
\text { authors is from } \\
\text { Emerging countries } \\
(55 \%), \text { USA (15\%), } \\
\text { Italy (10\%), Rest of } \\
\text { Europe (20\%) }\end{array}$ & $\begin{array}{c}\text { Applied financial economics, } \\
\text { Banks and bank system, } \\
\text { International journa of } \\
\text { monetary economics and } \\
\text { finance, Journal of financial } \\
\text { intermediation, Journal of } \\
\text { financial economics }\end{array}$ \\
\hline $\begin{array}{c}\text { Banks Credit, } \\
\text { enterprise, } \\
\text { Italy }\end{array}$ & 6 & Italy (100\%) & $\begin{array}{c}\text { Contributions to Economics, } \\
\text { International Journal of Risk } \\
\text { Assessment and Management, } \\
\text { Small Business Economics, } \\
\text { CESifo Economic Studies, } \\
\text { Journal of Knowledge } \\
\text { Management, Applied Financial } \\
\text { Economics } \\
\end{array}$ \\
\hline Italan Bank & 211 & $\begin{array}{l}\text { The majority of } \\
\text { authors is from Italy } \\
(75 \%) \text {, Rest of } \\
\text { Europe }(20 \%) \text {, USA } \\
(5 \%)\end{array}$ & $\begin{array}{c}\text { International journal of Central } \\
\text { Banking, Academy of } \\
\text { accounting and financial } \\
\text { studies journal, Applied } \\
\text { financial economics, Financial } \\
\text { crisisi bank behaviour and } \\
\text { credit crunch, Journal of bankin } \\
\text { end finance }\end{array}$ \\
\hline
\end{tabular}

(Reference - Author)

In the Table 1 is possible to find a summary about the data set, in the firs column there are the key words searched in scopus, in the second column there is the number of document extracted for each one key words searched, in the third column there are nationality of authors and at the last column there are the most important journals and conference proceedings where are published the documents. 
The above articles highlight that following the harsh economic crisis that struck the entire international system between 2007 and 2010, affecting the economic results and financial performances of credit institutions, national and international authorities introduced specific regulations and strengthened the existing ones radically influencing the whole credit sector.

The first steps towards imposing constraints to the conduct adopted by banks were made by the Basel Committee in 1988 with the introduction of the minimum capital requirement aimed at protecting deposits from the risk that bank assets undergo losses thus becoming insufficient to face credit risk (loans to customers) and market risk (direct investments).

The above mentioned capital restraint had, however, considerable gaps to be filled in order to be enforced and therefore it underwent a long and complex revision that resulted in the final approval of the agreement called Basel 2 in June 2004 and entered into force in 2008 (Ayadi, N., et. al. 2014, Pg 203-226).

This new regulation introduced three main pillars, as specified in appendix 1:

1. Capital requirements;

2. Supervisory review;

3. Market discipline.

These modify and better define the criteria for assessing minimum capital requirements and introduce the operational risk (banking organization as a whole) (Peek, J., 2014, Pg 71-110), while the supervisory review aims at increasing the powers of the Supervisory Authorities responsible for verifying the application by credit institutions of organizational procedures and policies for the assessment and management of their risks (Calì, C., et. al. 2014, Pg 221-251).

Under the market discipline, the agreement requires Banks to give more information to the market enabling stakeholders to assess in a clear and transparent manner a bank's risk and capital conditions.

It appears clear that, as credit institutions must bind their capital to the risks connected to their business, these also depend on the credit risk of the companies receiving the credit. Consequently, banks will ask companies to reduce their financial risk in order to improve their rating (thus reducing credit risk) in order to have less risk capital linked to lending to their clients (Colombini, F., 2015, Pg 236-273).

A lower invested capital means, for banks, the possibility to use the same for other purposes. Conversely, a greater invested capital results in the loss of investment opportunities, which cost necessarily affects companies under the form of increased rates for more risky companies. 
In response to the 2007-2010 economic crisis, on 12 September 2010 the Governors and Heads of Supervisory Authorities of the G20 Countries approved the proposals made by the Basel Committee (Basel 3 - the principal pillars are indicated in following appendix 1) which were submitted to the Heads of State and Government in Seoul in November 2010 (Luo, D., et. al. 2014, Pg 5-21).

This reform aims at preventing excessive risk-taking by operators, making the financial system stronger and establishing a really consistent playground (McCann, F., et. al. 2015, Pg 3594-3611). The measures introduced by this latest reform will only concern financial intermediaries and they specifically provide as follows:

1. Introduction of minimum liquidity standards;

2. Definition of regulatory capital and establishment of higher capital requirements;

3. Better market and counterparty risk hedging;

4. Containment of the level of financial leverage;

5. Countercyclical measures to reduce procyclicality in prudential rules.

This latest reform of the Basel Agreement had important consequences in the banking system in general and specifically in the credit relationship with the entrepreneurial system.

Basel 3 "philosophy" is simple: all the transactions a bank carries out (sale of securities, granting of credits, etc.) entail some risks and, therefore, possible losses (Berg, G., et. al. 2015, Pg 951-990).

The higher the risks, the greater the possible losses and the larger the amount of money a bank must provide to protect itself and which cannot be used in any way: this is money to keep in the safe for possible emergencies.

Compared with the previous Agreements (1998 e 2008), the new provisions, introduced in a still uncertain economic situation, increase proportionally the provisional capital credit institutions must hold for "security".

Consequently, banks suffer increased costs and this is reflected on their clients in terms of higher commissions and spreads on bank loans (Iren, P., et. al. 2014, Pg 374-417).

Therefore, companies should expect to undergo a closer inspection than before when asking for money from a credit institution.

Companies' ratings are more and more accurately assessed and are more and more decisive for at least two decisions: if and how much money to lend and at what costs and terms. (See Appendix) 


\section{CONCLUSION}

The literature analyzed shows that with the search made and in response to our research question 1, it is possible to detect the following main topics:

- Emerging countries;

- Risk analysis;

- Advanced technology;

- Banking regulation, role of the rules on the level and composition of capital;

- Impact of the regulation on the territory and the real economy.

We answered the second RQ on the analysis of the literature and examined how the rules regulating the bank-company relationship have influenced the economic system. The lending policies adopted by Italian banks were strongly influenced by the regulation, and specifically by Basel 2 and Basel 3, thus imposing on Credit Institutions minimum capital requirements directly proportionate to risk management and hedging, binding them to loan disbursement.

The necessary requirements and conditions for a company to be granted credit by a bank appear, therefore, to be directly influenced by regulatory constraints on the quality of capital assets and the possibility of deterioration of the portfolio and the capital. Consequently, the bank-company relationship and the economic system were strongly influenced by Community regulation and, therefore, the credit crunch may be considered as an event more associated with the criteria adopted to assess creditworthiness than with industrial crisis (Leo S., 2016, Pg 84-105).

In light of the above, our research will continue focusing on banking regulation, its impact on the composition and quantity of banks' capital and how this affects the economic and financial system of the Country.

This will enable us to give a more thorough answer to the second research question.

During the financial crisis the banking sector suffered significant losses, the recession preceded by a high credit expansion makes unstable the banking sector, causing a contraction in the real economy, which further worsens the banking system.

The close relationship between the banking system and the economic system and the need for the banking system to provide capital reserves during credit expansion periods have led the Basel Committee to determine the scope of the assets to defend the banking sector in the periods of increased credit expansion.

In addition to the capital requirements, minimum levels have also been set for liquidity requirements, in fact, during the financial crisis, while meeting 
the capital requirements, many banks have experienced several difficulties due to mismanagement of liquidity.

The crisis has highlighted the importance of this aspect for the proper functioning of financial markets and the banking sector, banks, in the face of serious liquidity situations, requested the intervention of the Central Banks, in the face of all this, the Basel Committee has introduced a number of minimum requirements on liquidity to be maintained by lending institutions.

The new Basel agreement is reflected in the business system, as the new rules create, in many circumstances, further credit access problems, in particular, this phenomenon occurs in small and medium-sized enterprises in SMEs, characterized by strong propensity to short-term bank debt.

The weak and fragile SME financial structure worsened with the entry into force of Basel 3 as it contains stricter parameters for the protection of the capital of banks.

SMEs are often faced with liquidity problems and therefore seek credit to continue their business, after examining their budgets, banks tend to assess the risk of default, whether or not they grant credit or vary the interest rates applied.

The goal of Basel 3 is to get a solid and risk-free banking system, makes it extremely difficult to access credit for SMEs, causing obstacles to the economic recovery that necessarily needs credit.

The objective of Basel 3, which is to strengthen bank solidity, must necessarily be associated with adequate credit flows to households and businesses in order to secure economic recovery and a prospect for development for the future.

\section{REZIME \\ ODNOSI IZMEĐU BANAKA I KOMPANIJA: PREGLED LITERATURE}

Ovaj rad ima za cilj pregled nacionalne i međunarodne literature o kreditnim odnosima između banaka i kompanija u Italiji u svetlu regulatornih promena koje je u različitim verzijama uveo Bazelski komitet, kako bi se razumele najnovije odluke i kako su i do koje mere ova pitanja razmatrana u različitim studijama do sada.

Rad je zasnovan na pregledu literature o promenjenim odnosima između banaka i kompanija u godinama. nakon ekonomske krize. U tu svrhu, u okviru Scopus-a je sprovedeno bibliografsko istraživanje, na osnovu niza odabranih ključnih reči. Identifikovane publikacije su analizirane i klasifikovane, u pokušaju da se utvrde glavne teme i rezultati dobijeni zahvaljujući istraživanju i analizama koje su do sada izvršene. 
Doprinos rada ogleda se u pregledu literature na temu odnosa između banaka i kompanija i predlaže novu perspektivu koja se odnosi na pitanje koje je od velikog značaja pogotovo u periodu ekonomskog oporavka kada je finansijska podrška kompanijama od presudnog značaja. Pregledom literature ustanovljeno je da ovo pitanje nije dublje proučavano naročito pitanja vezana za traženje i dostupnost eksternih izvora finansiranja, što otvara mogućnost identifikovanja novih pitanja i pronalaženja novih rešenja vezana za probleme održivosti kako javnih tako i privatnih investicija.

Ključne reči: banke, kompanije, krediti, italijanske banke, ekonomska kriza, regulativa

\section{REFERENCES}

1. Ayadi, N., Boujèlbène, Y., (2014) The role of capital regulation on bank performance, International Journal of Managerial and Financial Accounting - Volume 6, Issue 3, Pages 203-226.

2. Albertazzi U., Ropele, T., Sene, G. e Signoretti F.M., (2014) The impact of the sovereign debt crisis on the activity of Italian banks, Journal of Banking and Finance - Volume 46, Issue 1, Pages 387-40.

3. Bartoli F., Murro P., e Rotondi Z., (2014) Bank support and export: evidence from small Italian firms, Small Business Economics - Volume 42, Issue 2, Pages 245-264.

4. Bartolini M., Gardini S., Savioli G., (2014) International financial reporting standards and SMEs: The effects on firm rating according to Basel I, International Journal of Accounting, Auditing and Performance Evaluation - Volume 10, Issue 1, Pages 43-67.

5. Berg, G., Kirschenmann, K., (2015) Funding versus real economy shock: The impact of the 2007-09 crisis on small firms' credit availability, Review of Finance - Volume 19, Issue 3, Pages 951-990.

6. Borri N., Caccavaio M., Giorgio G.D., Sorrentino A.M., (2014) Systemic risk in the italian banking industry, Economic Notes - Volume 43, Issue 1, Pages 21-38.

7. Brighi P., Venturelli V., (2016) How functional and geographic diversification affect bank profitability during the crisis, Finance Research Letters - Volume 16, Pages 1-10.

8. Calì, C., Marchitto, B., Resti, A., (2014) Systemic risk and bank crises: Lessons from banking industry ratings, International Journal of Banking, Accounting and Finance - Volume 5, Issue 3, Pages 221-251. 
9. Colombini, F., (2015) Risk, regulation, supervision and crises in the European Banking Union, Law and Economics Yearly Review - Volume 4, Issue 2, Pages 236-273.

10. Gallo M. e Vannoni V., (2015) The Determinants Of Bank Interest Rates In Italian Regions, Scienze Regionali - Volume 14, Issue 1, Pages 67-84.

11. Gou Q., Huang Y., Xu J., (2016) Does ownership matter in access to bank credit in China, European Journal of Finance - 8 June 2016, Pages 1-23.

12. La Rocca M., Deloof M., (2015) Local financial development and the trade credit policy of Italian SMEs, Small Business Economics - Volume 44, Issue 4, Pages 905-924.

13. Leo S., (2016) Capital requirements and credit policies in Italy: what effects do they have?, International Journal of Risk Assessment and Management - Volume 19, Issue 1-2, Pages 84-105.

14. Luo, D., Ying, Q., (2014) Political connections and bank lines of credit, Emerging Markets Finance and Trade - Volume 50, Pages 5-21.

15. Modina M., Peitrovito F., (2014) A default prediction model for Italian SMEs: the relevance of the capital structure, "Applied Financial Economics - Volume 24, Issue 23, Pages 1537-1554.

16. McCann, F., McIndoe-Calder, T., (2015) Firm size, credit scoring accuracy and banks' production of soft information, Applied Economics - Volume 47, Issue 33, Pages 3594-3611.

17. Obokoh L.O., Monday J.U., Ojiako U., (2016) Microfinance banks and small and medium sized companies access to finance: The Nigerian experience, Banks and Bank Systems - Volume 11, Issue 1, Pages 71-81 and 6.

18. Peek, J., (2014) The impact of credit availability on small business exporters, Small Business Exports: Analyses of Promotion Programs and Impact of Credit Availability, Pages 71-110.

19. Peruta M.R.S., Campanella F., Giudice M.D., (2014) Knowledge sharing and exchange of information within bank and firm networks: The role of the intangibles on the access to credit, Journal of Knowledge Management - Volume 18, Issue 5, Pages 1036-1051.

20. Riccio G., (2016) Direct access to the debt capital market by unlisted companies in Italy and the effects of changes in civil Law: An empirical investigation., Contributions to Economics - Volume 214, Pages 179-193.

21. Saeed A., Sameer M., (2015) Financial constraints, bank concentration and SMEs: evidence from Pakistan, Studies in Economics and Finance Volume 32, Issue 4, Pages 503-524.

22. Shafi A.A., Ajay G.K., Muchie M., (2016) Influence of access to bank credit on companies productivity in Ethiopia: Does credit matter to improve productivity?, International Business Management - Volume 10, Issue 9, Pages 1679-1686. 
23. Stefani M.L. e Vacca V., (2015) Small firms' credit access in the Euro area: Does gender matter?, CESifo Economic Studies - Volume 61, Issue 1, Pages 165-201.

24. Rossi S.P.S. e Malavasi R., (2015) Financial crisis, bank behaviour and credit crunch, Financial Crisis, Bank Behaviour and Credit Crunch - Pages 1-193.

\section{APPENDIX 1}

The following table explains all the conditions under which the legislation came with the latest Basel agreement.

\begin{tabular}{|c|c|c|c|c|c|}
\hline \multicolumn{5}{|c|}{ CAPITAL } & \multirow{2}{*}{$\begin{array}{c}\text { LIQUIDITY } \\
\text { GLOBAL LIQUIDITY STANDARD } \\
\text { AND SUPERVISORY } \\
\text { MONITORING }\end{array}$} \\
\hline CAPITAL & RISK COVERAGE & CONTAINING LEVERAGE & $\begin{array}{l}\text { RISK MANAGEMENT } \\
\text { AND SUPERVISION }\end{array}$ & $\begin{array}{c}\text { MARKET } \\
\text { DISCIPLINE }\end{array}$ & \\
\hline Quality and level of capital & Securitisations & \multirow{4}{*}{$\begin{array}{l}\text { Leverage ratio } \\
\text { A non-risk-based } \\
\text { leverage ratio that } \\
\text { includes off-balance } \\
\text { sheet exposures will } \\
\text { serve as a backstop to } \\
\text { the risk-based capital } \\
\text { requirement. Also helps } \\
\text { contain system wide } \\
\text { build up of leverage. }\end{array}$} & \multirow{4}{*}{\begin{tabular}{|l} 
Supplemental Pillar 2 \\
requirements. \\
Address firm-wide \\
governance and risk \\
management; \\
capturing the risk of \\
off-balance sheet \\
exposures and \\
securitisation \\
activities; managing \\
risk concentrations; \\
providing incentives \\
for banks to better \\
manage risk and \\
returns over the long \\
term; sound \\
compensation \\
practices; valuation \\
practices; stress \\
testing; accounting \\
standards for financial \\
instruments; \\
corporate governance; \\
and supervisory \\
colleges.
\end{tabular}} & \multirow{4}{*}{\begin{tabular}{|l|} 
Revised Pillar 3 \\
disclosures \\
requirements \\
The requirements \\
introduced relate \\
to securitisation \\
exposures and \\
sponsorship of off- \\
balance sheet \\
vehicles. Enhanced \\
disclosures on the \\
detail of the \\
components of \\
regulatory capital \\
and their \\
reconciliation to \\
the reported \\
accounts will be \\
required, including \\
a comprehensive \\
explanation of how \\
a bank calculates \\
its regulatory \\
capital ratios.
\end{tabular}} & Liquidity coverage ratio \\
\hline $\begin{array}{l}\text { Greater focus on common } \\
\text { equity. The minimum will be } \\
\text { raised to } 4.5 \% \text { of risk- weighted } \\
\text { assets, after deductions. }\end{array}$ & $\begin{array}{l}\text { Strengthens the capital } \\
\text { treatment for certain complex } \\
\text { securitisations. Requires } \\
\text { banks to conduct more } \\
\text { rigorous credit analyses of } \\
\text { externally rated securitisation } \\
\text { exposures. }\end{array}$ & & & & $\begin{array}{l}\text { The liquidity coverage ratio } \\
\text { (LCR) will require banks to have } \\
\text { sufficient high- quality liquid } \\
\text { assets to withstand a } 30 \text {-day } \\
\text { stressed funding scenario that } \\
\text { is specified by supervisors. }\end{array}$ \\
\hline $\begin{array}{l}\text { Capital loss absorption at the } \\
\text { point of non-viability } \\
\text { Contractual terms of capital } \\
\text { instruments will include a clause } \\
\text { that allows - at the discretion of } \\
\text { the relevant authority - write- } \\
\text { off or conversion to common } \\
\text { shares if the bank is judged to } \\
\text { be non-viable. This principle } \\
\text { increases the contribution of } \\
\text { the private sector to resolving } \\
\text { future banking crises and } \\
\text { thereby reduces moral hazard. }\end{array}$ & \begin{tabular}{|l|} 
Trading book \\
Significantly higher capital for \\
trading and derivatives \\
activities, as well as complex \\
securitisations held in the \\
trading book. Introduction of \\
a stressed value-at-risk \\
framework to help mitigate \\
procyclicality. A capital charge \\
for incremental risk that \\
estimates the default and \\
migration risks of \\
unsecuritised credit products
\end{tabular} & & & & $\begin{array}{l}\text { Net stable funding ratio } \\
\text { The net stable funding ratio } \\
\text { (NSFR) is a longer-term } \\
\text { structural ratio designed to } \\
\text { address liquidity mismatches. It } \\
\text { covers the entire balance sheet } \\
\text { and provides incentives for } \\
\text { banks to use stable sources of } \\
\text { funding. }\end{array}$ \\
\hline $\begin{array}{l}\text { Comprising common equity of } \\
2.5 \% \text { of risk-weighted assets, } \\
\text { bringing the total common } \\
\text { equity standard to } 7 \% \text {. } \\
\text { Constraint on a bank's } \\
\text { discretionary distributions will } \\
\text { be imposed when banks fall into } \\
\text { the buffer range. }\end{array}$ & $\begin{array}{l}\text { Substantial strengthening of } \\
\text { the counterparty credit risk } \\
\text { framework. Includes: more } \\
\text { stringent requirements for } \\
\text { measuring exposure; capital } \\
\text { incentives for banks to use } \\
\text { central counterparties for } \\
\text { derivatives; and higher capital } \\
\text { for inter-financial sector } \\
\text { exposures. }\end{array}$ & & & & $\begin{array}{l}\text { Principles for Sound Liquidity } \\
\text { Risk Management and } \\
\text { Supervision } \\
\text { The Committee's } 2008 \\
\text { guidance Principles for Sound } \\
\text { Liquidity Risk Management and } \\
\text { Supervision takes account of } \\
\text { lessons learned during the crisis } \\
\text { and is based on a fundamental } \\
\text { review of sound practices for } \\
\text { managing liquidity risk in } \\
\text { banking organisations. }\end{array}$ \\
\hline
\end{tabular}

Ovaj rad je primljen 13.11.2017., a na sastanku redakcije časopisa prihvaćen za štampu 16.01.2018. godine. 